\title{
Development of Character Strategies by Coaches for University Athletes in Niger Delta Region of Nigeria
}

\author{
Dada, Benson Olu, (Ph.D) ${ }^{1}$ \\ ${ }^{I}$ (Department of Human Kinetics and Health Education, Delta State University, P.M.B 1 Abraka, Nigeria)
}

\begin{abstract}
It is strongly viewed that sport and physical activity setting possess potential for athlete's character development. Some others argue that sports may not build character except it is structured with strategies to do so. This study focused on development of character development strategies by coaches for university athletes in Niger Delta of Nigeria. Forty-six sports coaches of universities constitute population and sample for the study. The modified Research and Development design by Borg and Gall was adapted for the study. Two questionnaires, one for identifying character strategies by coaches and the other for matching character traits to strategies identified by coaches were used for data collection. The content and construct validity were estimated using factor analysis. The rotated component matrix for construct validity ranging from $0.57-0.87$ extracted eleven items at 68.74 cumulative percentage. Using the Cronbach Alfa statistics, a coefficient of 0.81 0.89 at 0.05 was accepted as reliability index for moral and social character. A criterion mean of 3.00 and above was a benchmark for adopting strategies while percentages were used for matching strategies to character traits. The findings amongst other show that coaches emphasizing the importance of integrity and honesty in sport, enforcing sanctions on rule-breakers and use of moral worded watchwords build moral character. While the organization of peer discussion and dialogue was adopted for building the social character. It is recommended amongst others that: coaches should be given orientation or training on the development of athlete's character through sports.
\end{abstract}

Keywords: Character, Development, University Athletes, Strategies, Coaches.

\section{Introduction}

In most recent times, educational and sports institutions have strongly viewed and used sports as a vehicle for developing character ([1]; [2] \& [3]). Character development through sports participation has long been a topic of interest to educators and academics. In higher education character development has been considered an important objective of education, in general [4]; [5], athletic participation in particular [6]. Positive character traits such as moral and social responsibility were believed can and should be taught and learned in a sport and physical activity setting [7], [8] defines character as a complex set of relatively enduring qualities of the person, and has a positive connotation when used in discussions of moral education. Character is the habit established at first through the training from youth, of taking responsibility for oneself, of being brave, of being honourable and of using our reason or intelligence to guide our feelings, especially when our feelings might lead us to do something unwise, unloving, disrespectful, unfair, and dishonest [9].

It appears that character has a combination of moral and social values. These two dimensions of character values need to be properly defined so that appropriate character development strategies can be identified for University Athletes in the Niger Delta. The concept of moral character originated from Aristotle over 2000 years ago. Aristotle believed a person of moral character was someone who conducted himself or herself by moral principles such as honesty, fairness, and compassion [6]. A true test of character is when one can apply moral principles in the face of competing societal pressures and temptations. When moral values are violated, harm to individuals often ensues. For example, a relationship in which person A is continually dishonest to person B will most likely lead to an unhealthy and dysfunctional relationship [10]. Similarly, in a sports context, the maintaining of moral values such as honesty, fairness and respect are vital to a fair and healthy competition between opponents.

Sports administrators and governing bodies are becoming more concerned about the nature of character manifested by athletes during play. [11] observed that character of sports participants during competitions has become a topic that has drawn much attention in many countries the world over. There is growing national and international concern about ethical issues bordering on character development in sports. These include a decline in the standard of gentlemanly conduct, the lack of respect for officials, tacit acceptance of rule bending, parental pressure and violence on the field ([12]; [13]). The situation in Nigerian university sports is not different as athletes attempt to use different tactics to get second meal tickets and swindle allowances of others during sports meets. Non university athletes who were not officially admitted are given fake admission credentials to enable them to participate. Athletes are, sometimes, dumped from competition for engaging in acts contrary to camping regulations. Reports of athletes engaging in unethical acts out of the field such as 
Development of Character Strategies by Coaches for University Athletes in Niger Delta Region of ..

dishonest dealings with friends, lovers and or games officials are topical news in the media. These reports indicate that athletes are failing to demonstrate character values which the society is expecting. The above scenario underscores the need for character development strategies for coaches especially in the Niger Delta area of Nigeria.

The jury reports on the 21st NUGA of the University of Maiduguri from 15-24th February 2007 further reveals the character of University athletes in Nigeria and the Niger Delta particularly. The appeals and protests showed that even many athletes felt cheated. The protests and appeals include inconsistencies on admission letters and registration procedures manipulated to engage non-university athletes. Impersonation and the use of mercenaries in the competition were identified. The jury after adjudication disqualified Thirty-eight athletes who were not bona fide student athletes. In addition the entire handball and cricket teams of two Universities were mercenaries. The panel further observed a decline in moral standards of the game as athletes and university sport officials engage in illegal and un-sportsman-like practices to win medals. This report indicates that University coaches, athletes, and even University Administrators are involved in nurturing bad character which sport participation is supposed to build. The report revealed that university athletes are engaging themselves in unsportsman-like character such as trying to win at all cost. University teams use all forms deceit to out manouvre opponent teams. During the 2008 games, it was difficult to commence the swimming event due to protests that mercenaries were fielded by certain universities from Niger Delta region. This resulted in an impasse preceding the swimming event. It was observed by some coaches that athletes from Niger Delta are being marketed among universities in a bid to win at -all cost. Thus, it becomes imperative to empirically determine the status of university athletes' character and character development strategies to forestall moral character decadence in sport, which are the primary thrust of this study.

Character development is engaging in activities that produce a change in the individual that is synonymous with character education. Character education refers to the deliberate and intentional activity of cultivating, modeling and teaching moral growth and moral development [14]. The goal of this process is for an individual to build moral habits with a disposition to act upon moral judgment [15]. It involves teaching young people the knowledge, attitudes, beliefs, skills and behaviour to be fair, kind and good.Sport teaches the value of practice and personal development besides providing a pseudo environment that allows for correction and modification within the bounds of real life. This is because, according to Austin [16] sports can build character but it does not happen automatically, we must intentionally make it happen. Thus, with a proper teaching and coaching that also emphasized on character development, sports and physical activity can be an appropriate platform for building a character [17]. Character is not caught but taught in a sport. Hence, character development must be systematically taught to players. The terms character and moral development have been used interchangeably and can be interpreted quite differently depending on one's perspective. Moral development has been used as an umbrella term encompassing concepts such as sportsmanship, character, pro social behaviour and fair play [18]. In this study character development and moral development will be used interchangeably. They refer to the cognitive process individuals experience as they develop the capacity to reason about moral issues that arise in a sports environment. It includes situation where athletes are challenged to balance their rights and responsibilities simultaneously with the rights and responsibilities of others. There is scarcely any investigation designed to investigate strategies utilized to develop character and good morals through sport of a Nigeria context. It is observed that the scientific community has learned little about the strategies coaches use on day to day basis to develop character and good skills which is necessitating the need for character development strategy for coaches of university athletes in Niger Delta.

Several theories and conceptual approaches highlight the strategies by which coaches may foster character development among university athletes. Social learning theory [19], proposes that individuals learn character through observational learning and social reinforcement. This implies that coaches can serve as role models and distribute rewards for fascinating character in sports. Structural development theory ([20]; [21]) propose that individuals reach more mature levels of moral reasoning by experiencing moral dilemmas and finding balance among their own and others interest through discussion. Coaches can take advantage of such situations in sport by engaging athletes in meaningful dialogue that challenges them to consider others wellbeing. Positive athletes character development can be fostered by participating in activities that provide opportunities for skill building and engaging in interactions with supportive adults such as the coach [22]. Coaches who set expectations for positive character can build supportive relationships and create an empowering environment that positively influence personal responsibility, caring for others and contribute to society. The structural and social learning theorists provide insight on how coaches might influence university's athlete social and moral character development. These theories and conceptual approaches provide insight on how coaches might develop university athlete sportsmanship and moral character development.

Theory-driven research suggests that coaches can make an impact on athletes' character, in at least four ways modeling, social approval, motivational climate, and dialogue about and resolution of moral dilemmas. First, modeling is a powerful strategy by which youth learn about sportsmanship from watching coaches 
desirable or undesirable behaviors ([23]; [24]). In line with social learning theory, coaches modeling of morally appropriate or inappropriate behaviors will likely influence players to own moral actions. Second, the degree to which youth perceive that coaches approve or disapprove of sportsmanlike and unsportsmanlike behaviors affect their attitudes and character ([25]; [26]). Consistent with structural developmental theory, intervention studies show that instructors who addressed morally-arousing situations through meaningful discussion helped youth adopt mature moral reasoning and display pro-social behaviours. Collectively, these studies suggest that coaches influence youth sportsmanship and character development through numerous social strategies.

Strategy in this study means a scheme of activities and skills that should be espoused to University athletes to bring about positive character development through sports participation. These activities should be focused on developing character among males and females within the various sport-types. It has been observed that sport and physical activity may not promote or facilitate character and its unique virtues unless appropriate and efficiently designed strategies are introduced to enhance character development [27]. If the goal of the coach is to stress the concept of character development, he/she has to adopt or design a plan that is based upon this objective.

Despite theoretical frameworks and empirical studies that point to coaches as important sources for fostering character development of athletes less research has focused on strategies they adopt to build character. A limitation that necessitates investigation of character is that moral and social character development theory and research has not guided any study of strategies coaches use to develop character of University athletes in Nigeria.

The finding of this study will provide a theoretical framework that can be utilized to develop university athletes' character. The study may equally provide theory driven strategies that will be used by coaches to enhance character development of university athletes. It offers a platform for coaches to appreciate the application of moral character development theories in the scheme for character development.

\subsection{Purpose of the Study}

The purpose of this study is to determine character development strategies for coaches of university athletes in the Niger Delta. Specifically the study will determine:

Research questions:

i. What are the strategies for moral character development of university athletes for coaches in the Niger Delta?

ii. What are the strategies for social character development of university athletes for coaches in the Niger Delta?

\section{Methods}

The Research and Development design was adapted to identify strategies for developing university athletes' character in the Niger Delta. Research \& Development design was considered appropriate because it enabled a proper field testing and validation of strategies for developing character of university athletes [28]. Borg and Gall opined that in using this design as thesis or dissertation requires scaling down of the project to limit the development to just a few steps the Rand D cycle. The successful application of this design by [29] and [30] who modified and scaled down their projects to only six and seven steps respectively, to develop Healthy Ageing Intervention Model and Crisis Management Model for Soccer Clubs in South Eastern States of Nigeria respectively, suggested a success in its use for Character Development Strategies for coaches of University Athletes in the Niger Delta. Six steps of the design were adapted in this present study that includes the following:

Step I: Research reports and information collection

This involved an assessment of the current situation of the character of university athletes in the Niger Delta. A review of literature on the state of university athletes' character in the world and Nigeria. Reports from WISCONSIN Intercollegiate Athletic Council [35], Australian coaching council and Nigerian University Games association report of Jury appeal for the 21 st games were consulted. This was followed with a baseline study using descriptive survey design to ascertain the current status of the university athletes character was conducted in the Niger Delta.

Step II: Planning

This involved identification of skills values and activities that are essential for character development such as moral dialogue, discussions, fair play, responsibility, respect, care, sports fairs, league competitions and lots more were identified with methods of application. 
Development of Character Strategies by Coaches for University Athletes in Niger Delta Region of ..

Step III: Validation of character development strategies

A preliminary draft of the skills and activities for inclusion was subjected to face validation by a team of experts in the field of sport, sociology, measurement and evaluation. This resulted in modification of proposed strategies based on the recommendation of the experts.

Step IV: Preliminary field testing

The instrument was used to generate data from coaches from Nnamdi Azikiwe University Awka and the University of Nigeria, Nsukka for reliability and factor analysis.

Step V: Main field testing

The validated version of the instrument was sent to the universities sampled in the Niger Delta for data collection. The data collected were used for statistical analysis to answer research questions and test hypothesis proposed for the study.

Step VI: A final draft of the strategies identified by coaches in the Niger Delta.

The draft of strategies embodies the character scenarios, which was cross matched with the targeted traits and strategies that were identified to address moral, social and sportsmanship improvement.

Forty-six coaches constitute the population. All the coaches identified by the sports directors of the University were used for the study, and there was no sampling. Two questionnaires were designed. The first is University athletes' character development strategies questionnaires (UACDSQ). Based on literature review, a 17 item questionnaire put in three sections were constructed for the study. Section A consists of personal data of the respondents Coach, B has nine questions on good character strategies, C, has eight questions on social character strategies while section. Sections B and C has a 4 point rating scale question of very appropriate, (VA) appropriate (A) not appropriate (NA) not very appropriate (NVP). The second questionnaire determined the suitability of the strategies for resolving the character problems. Coaches were asked match character trait items against validated strategies. Five experts considered the items in the instrument adequate regarding clarity, appropriateness of language and its ability to elicit the required information solicited. The content and construct validity of the instrument were estimated using factor analysis. The varimax with Kaizer normalization methods principal components analysis (PCA) and the extraction method were used in extracting the content and construct validity. The construct validity of the instrument was estimated with rotated component matrix, with Kaizer normalization and for content validity with rotated sum of square loadings. The eigenvalues above one were used to select factors that genuinely measure similar constructs.

The social character strategies, with eleven items, 8 were extracted with rotated components matrix ranging from $0.62-0.86$. These scores are an indication that the items have construct validity. The rotated sum of square loading shows a cumulative variance of $62.17 \%$. The moral character strategies indices with eleven items, all the items were extracted with rotated components matrix ranging from $0.57-0.87$. These scores indicate good content validity. The rotated sum of squares shows that a cumulative percentage of $68.74 \%$ are indication of high construct validity. The cronbach statistics was used to determine reliability and it yielded a coefficient alpha of 0.89 at $(\mathrm{P}<0.05)$. The social character subscale yielded 0.81 Therefore the UACDSQ was considered to have a good reliability measure for this study. The item mean was computed and used to select character development strategies. Any item above a mean score of 3.00 was considered appropriate. The simple percentage was used to determine the result of matched items

\section{Result}

Research Question One

What is the mean score of moral character development strategies of coaches for university athletes in the Niger Delta?

Table 1: Mean scores Moral Character development strategies of Coaches

\begin{tabular}{|l|l|c|c|c|}
\hline S/N & \multicolumn{1}{|c|}{ STRATEGIES } & $\begin{array}{c}\text { COACH } \\
\mathbf{N = 4 6} \\
\bar{x}\end{array}$ & SD & Decision \\
\hline 1. & $\begin{array}{l}\text { Coaches and athletes should devote substantive portion of post-practice briefing } \\
\text { sessions to discuss and stress the importance of integrity and honesty in sport. }\end{array}$ & 3.68 & .55 & $\mathrm{~A}$ \\
\hline 2 & $\begin{array}{l}\text { Coaches should demonstrate transparency in dealing with issues concerning } \\
\text { fielding of athletes during competitions }\end{array}$ & 3.50 & .66 & $\mathrm{~A}$ \\
\hline 3 & $\begin{array}{l}\text { Coaches should organize moral dilemma discussions on the ethical implications } \\
\text { of deceit in sport. }\end{array}$ & 3.41 & .58 & $\mathrm{~A}$ \\
\hline 4 & $\begin{array}{l}\text { Captain should instruct team members to produce monthly watch words on fair } \\
\text { treatment of opponents in sport. }\end{array}$ & 3.28 & .62 & $\mathrm{~A}$ \\
\hline 5 & $\begin{array}{l}\text { Coaches and athlete should be involved in moral reasoning and moral dilemma } \\
\text { discussions in resolving conflicts on ethical issues in sports. }\end{array}$ & 3.43 & .65 & $\mathrm{~A}$ \\
\hline 6 & Motivational speakers should be engaged to talk on the moral implications of & 3.63 & .53 & $\mathrm{~A}$ \\
\hline
\end{tabular}


Development of Character Strategies by Coaches for University Athletes in Niger Delta Region of ..

\begin{tabular}{|l|l|c|c|c|}
\hline & getting opponent injured deliberately to win in sport. & & \\
\hline 7 & $\begin{array}{l}\text { Athletes should regularly practice traditions that reinforce moral values of care } \\
\text { and compassion with coach led discussions before and during training sessions. }\end{array}$ & 3.46 & .62 & $\mathrm{~A}$ \\
\hline 8 & $\begin{array}{l}\text { Coaches should jointly develop a code of conduct with athletes to sanction rule- } \\
\text { breaking and impunity in sports. }\end{array}$ & 3.39 & .53 & $\mathrm{~A}$ \\
\hline 9 & $\begin{array}{l}\text { Athletes should organize public campaigns to highlight through discussion the } \\
\text { moral implication of using performance enhancing drugs in sport. }\end{array}$ & 3.65 & .54 & $\mathrm{~A}$ \\
\cline { 2 - 5 } & Grand Total & $\mathbf{3 . 5 0}$ & $\mathbf{. 5 9}$ & $\mathbf{A}$ \\
\hline
\end{tabular}

Criterion $\bar{x}=3.00 \quad$ Appropriate $=\mathrm{A}(\bar{x}>3.00) \quad \mathrm{NA}=\operatorname{Not}$ Appropriate $(\bar{x}<3.00)$

Table 1 shows that all the mean scores of coaches on the strategies are above the criterion mean of 3.00 and grand of 3.50, they were all accepted. Since all the mean scores are above the criterion mean (grand mean $3.50 \pm$ 0.59 ), it implies that all strategies are considered appropriate by coaches.

Table 2: Coaches Matching of Moral Character Strategies Against Moral Character Traits of University Athletes.

\begin{tabular}{|c|c|c|c|c|c|}
\hline $\mathbf{S} / \mathbf{N}$ & $\begin{array}{l}\text { Poor moral character } \\
\text { traits displayed in sport } \\
\text { by athletes }\end{array}$ & $\begin{array}{c}\text { Item no } \\
\text { of } \\
\text { strategy }\end{array}$ & Frequency & $\begin{array}{c}\text { Relative } \\
\text { frequenc } \\
y \\
\end{array}$ & Character development strategies \\
\hline 1 & $\begin{array}{l}\text { Players fake injury to gain } \\
\text { advantage over opponent }\end{array}$ & $\begin{array}{c}1 \\
2 \\
8 \\
9 \\
\text { Total } \\
\end{array}$ & $\begin{array}{c}7 \\
2 \\
9 \\
22 \\
40 \\
\end{array}$ & $\begin{array}{c}7.5 \% \\
5.0 \% \\
22.5 \% \\
55 \% \\
100 \% \\
\end{array}$ & $\begin{array}{l}\text { Coaches and athletes should devote } \\
\text { substantial portion of post-practice } \\
\text { briefing session to discuss and stress the } \\
\text { importance of integrity and honesty in } \\
\text { sport. }\end{array}$ \\
\hline 2 & $\begin{array}{l}\text { Athletes break game rules } \\
\text { if official will not catch } \\
\text { them. }\end{array}$ & $\begin{array}{c}1 \\
2 \\
7 \\
8 \\
\text { Total } \\
\end{array}$ & $\begin{array}{c}5 \\
31 \\
2 \\
2 \\
40\end{array}$ & $\begin{array}{c}12.5 \% \\
77.7 \% \\
5 \% \\
5 \% \\
100 \%\end{array}$ & $\begin{array}{l}\text { Coaches and athletes should develop } \\
\text { code of conduct that specify sanctions for } \\
\text { rule breakers. }\end{array}$ \\
\hline 3 & $\begin{array}{l}\text { Athletes support coaches } \\
\text { who locate matches in bad } \\
\text { playgrounds to gain } \\
\text { advantage over opponents }\end{array}$ & $\begin{array}{c}1 \\
3 \\
4 \\
\text { Total } \\
\end{array}$ & $\begin{array}{c}25 \\
8 \\
7 \\
40 \\
\end{array}$ & $\begin{array}{l}62.5 \% \\
20.0 \% \\
17.5 \% \\
100 \% \\
\end{array}$ & $\begin{array}{l}\text { Coach should instruct team members to } \\
\text { produce monthly watchwords on fair } \\
\text { treatment of opponents in sport }\end{array}$ \\
\hline 4 & $\begin{array}{l}\text { Athletes encourage } \\
\text { university coaches who } \\
\text { field non university athletes } \\
\text { in competitions. }\end{array}$ & $\begin{array}{c}4 \\
5 \\
\text { Total }\end{array}$ & $\begin{array}{l}20 \\
20 \\
40\end{array}$ & $\begin{array}{l}50 \% \\
50 \% \\
100 \%\end{array}$ & $\begin{array}{l}\text { Coaches should demonstrate } \\
\text { transparency on fielding of athletes. } \\
\text { Coaches should organize moral } \\
\text { reasoning discussions on use of } \\
\text { mercenaries in compositions. }\end{array}$ \\
\hline 5 & $\begin{array}{l}\text { Athletes protect teammates } \\
\text { who use performance } \\
\text { enhancing drugs in sport. }\end{array}$ & $\begin{array}{c}4 \\
6 \\
8 \\
\text { Total } \\
\end{array}$ & $\begin{array}{c}7 \\
26 \\
7 \\
40 \\
\end{array}$ & $\begin{array}{c}17.5 \% \\
65 \% \\
17.5 \% \\
100 \% \\
\end{array}$ & $\begin{array}{l}\text { Athletes should organize public } \\
\text { campaigns to highlight through } \\
\text { discussion the moral implication of using } \\
\text { performance enhancing drugs in sport. }\end{array}$ \\
\hline 6 & $\begin{array}{l}\text { Players retaliate bad play } \\
\text { by opponents in } \\
\text { competitions. }\end{array}$ & $\begin{array}{c}2 \\
7 \\
9 \\
\text { Total } \\
\end{array}$ & $\begin{array}{c}5 \\
27 \\
6 \\
40 \\
\end{array}$ & $\begin{array}{c}12.5 \% \\
67.5 \% \\
15 \% \\
100 \% \\
\end{array}$ & $\begin{array}{l}\text { Athletes should regularly practice } \\
\text { traditions that reinforce tolerance and } \\
\text { forgiveness in sport. }\end{array}$ \\
\hline 7 & $\begin{array}{l}\text { Players deliberately deceive } \\
\text { opponents to win in sport. }\end{array}$ & $\begin{array}{c}4 \\
8 \\
\text { Total } \\
\end{array}$ & $\begin{array}{c}7 \\
33 \\
40 \\
\end{array}$ & $\begin{array}{l}17.5 \% \\
82.5 \% \\
100 \% \\
\end{array}$ & $\begin{array}{l}\text { Coaches should organize moral dilemma } \\
\text { discussion on the ethical implications of } \\
\text { deceit in sport. }\end{array}$ \\
\hline 8 & $\begin{array}{l}\text { Players hurt opponents if } \\
\text { that will enable them win } \\
\text { the game }\end{array}$ & $\begin{array}{c}1 \\
3 \\
7 \\
9 \\
\text { Total } \\
\end{array}$ & $\begin{array}{c}3 \\
4 \\
3 \\
30 \\
40 \\
\end{array}$ & $\begin{array}{l}75 \% \\
10 \% \\
7.5 \% \\
7.5 \% \\
100 \% \\
\end{array}$ & $\begin{array}{l}\text { Motivational speakers should be engaged } \\
\text { to talk on the moral implications of } \\
\text { getting opponent injured deliberately to } \\
\text { win in sport. }\end{array}$ \\
\hline
\end{tabular}

From Table 2 above twenty-two coaches adopted the use of motivational speakers (55\%) as a strategy for players faking injury to gain advantage over opponents. On athletes breaking game rules if official would not catch them, $77.5 \%$ of the coaches accepted the strategy that coaches and athletes should develop code of conduct that specify sanctions for rule breakers to develop honesty. Twenty-five coaches $(62.5 \%)$ indicated that item no. 1 (coaches and athletes should devote substantial portion of post-practice briefing session to discuss and stress integrity and honesty) as strategy for athletes who support locating matches in bad play grounds to gain advantage. On athletes encouraging university coaches who field non university athlete in competitions, two strategies where adopted: that coaches should demonstrate transparency on fielding of athletes (50\%) and coaches should organize moral reasoning discussions on use of mercenaries for competitions (50\%). Twenty-six coaches $(65 \%)$ matched item 6 (athletes should organize public campaigns to highlight through discussions the moral implication of using performance enhancing drugs in sports) to athletes protecting teammates who use

DOI: 10.9790/6737-04021927 $\quad$ www.iosrjournals.org $23 \mid$ Page


Development of Character Strategies by Coaches for University Athletes in Niger Delta Region of ..

performance enhancing drugs in competitions. Similarly, twenty-seven coaches (67.5) adopted item 7 (athletes should regularly practice traditions that reinforce tolerance and forgiveness) as a strategy for players that retaliate bad plays by opponents. Thirty-three (82\%) accepted that coaches should organize moral dilemma discussions on the ethical implications of deceit in sport was matched against players deliberately deceive opponents to win in sports. Finally on moral character strategies, thirty coaches $(75 \%)$ endorsed the use of motivational speakers to highlight the moral implication of inflicting injury on opponents deliberately, against players hurt opponent if that will enable them win.

Research Question Two

What is the mean score of social character development strategies is of coaches of university athletes in the Niger Delta?

Table 3: Mean scores of social character development strategies of coaches.

\begin{tabular}{|c|c|c|c|c|}
\hline $\mathbf{S} / \mathbf{N}$ & STRATEGIES & $\begin{array}{c}\text { COACH } \\
\begin{array}{c}\mathrm{N}=46 \\
\bar{x}\end{array}\end{array}$ & SD & Decision \\
\hline 1. & $\begin{array}{l}\text { Sport fairs should be organized annually to promote and reward temperance and tolerance } \\
\text { in sports. }\end{array}$ & 3.54 & .54 & A \\
\hline 2. & $\begin{array}{l}\text { Explicit incentives relating to team sacrifice should be communicated to athletes at the } \\
\text { commencement of each sport season on loyalty. }\end{array}$ & 3.50 & .51 & A \\
\hline 3. & $\begin{array}{l}\text { Autobiography of outstanding sport heroes who demonstrated perseverance and patriotism } \\
\text { should be distributed to athletes to read for discussion subsequently. }\end{array}$ & 3.50 & .62 & A \\
\hline 4. & $\begin{array}{l}\text { Motivational speakers should be engaged to enlighten athletes on the need to be loving and } \\
\text { friendly to opponents. }\end{array}$ & 3.50 & .55 & A \\
\hline 5. & $\begin{array}{l}\text { Coaches should organize peer discussion on the importance of diligence and sacrifice as a } \\
\text { medium of earning success in sport. }\end{array}$ & 3.41 & .58 & A \\
\hline 6. & $\begin{array}{l}\text { Coaches and team captains should Organize cooperative interactive computer video } \\
\text { assisted programmes on team work and integration of new members. }\end{array}$ & 3.26 & .65 & A \\
\hline 7. & Players councils should be constituted to resolve intra team conflicts & 3.47 & .54 & A \\
\hline \multirow[t]{2}{*}{8} & Self-discipline to be inculcated through the principles of overload training & 3.41 & .58 & A \\
\hline & Grand Total & 3.45 & .57 & A \\
\hline
\end{tabular}

Criterion $\bar{x}=3.00$ Appropriate $=\mathrm{A}(\bar{x}>3.00)$, Not Appropriate $=\mathrm{NA}(\bar{x}<3.00)$.

Table 3 show that all the mean scores of coaches on the strategies are above the criterion mean of 3.00 and grand of 3.50, they were all accepted. Since all the mean scores are above the criterion mean (grand mean $3.45 \pm$ $0.59)$, it implies that all strategies are considered appropriate by coaches.

Table 4 Coaches matching of social character strategies against character traits of university athletes.

\begin{tabular}{|c|c|c|c|c|c|}
\hline $\mathbf{S} / \mathbf{N}$ & $\begin{array}{l}\text { Social Character Traits } \\
\text { Exhibited In Sport }\end{array}$ & $\begin{array}{l}\text { Item no } \\
\text { of } \\
\text { strategy }\end{array}$ & Frequency & $\begin{array}{l}\text { Relative } \\
\text { frequency }\end{array}$ & Social Character development strategies \\
\hline 1 & $\begin{array}{l}\text { Players are angry at their team } \\
\text { mates for making mistakes }\end{array}$ & $\begin{array}{c}1 \\
4 \\
5 \\
\text { Total }\end{array}$ & $\begin{array}{c}32 \\
4 \\
4 \\
40\end{array}$ & $\begin{array}{c}80 \% \\
10 \% \\
10 \% \\
100 \%\end{array}$ & $\begin{array}{l}\text { (1) Sport fairs should be organized periodically } \\
\text { to promote and reward athletes who display } \\
\text { temperance and tolerance in sport. }\end{array}$ \\
\hline 2 & $\begin{array}{l}\text { Players withdraw from } \\
\text { practicing difficult skills during } \\
\text { training sessions. }\end{array}$ & $\begin{array}{c}2 \\
3 \\
4 \\
\text { Total } \\
\end{array}$ & $\begin{array}{c}32 \\
3 \\
5 \\
40 \\
\end{array}$ & $\begin{array}{c}80 \% \\
7.5 \% \\
12.5 \% \\
100 \% \\
\end{array}$ & $\begin{array}{l}\text { (2) Autobiography of past model athletes that } \\
\text { demonstrated tenacity and perseverance should } \\
\text { be distributed to athletes to read before coach } \\
\text { led discussions. }\end{array}$ \\
\hline 3 & $\begin{array}{l}\text { Athletes obey game rules only } \\
\text { when it is convenient }\end{array}$ & $\begin{array}{c}2 \\
3 \\
4 \\
5 \\
\text { Total } \\
\end{array}$ & $\begin{array}{c}5 \\
29 \\
3 \\
3 \\
40 \\
\end{array}$ & $\begin{array}{l}12.5 \% \\
72.5 \% \\
7.5 \% \\
7.5 \% \\
100 \% \\
\end{array}$ & $\begin{array}{l}\text { (3) Explicit rewards and incentives relating to } \\
\text { total allegiance and obedience should be } \\
\text { communicated to athletes at commencement of } \\
\text { each sport season. }\end{array}$ \\
\hline 4 & $\begin{array}{l}\text { Players easily give up during } \\
\text { extra time in competitions. }\end{array}$ & $\begin{array}{c}4 \\
5 \\
6 \\
3 \\
\text { Total }\end{array}$ & $\begin{array}{c}32 \\
4 \\
1 \\
3 \\
40\end{array}$ & $\begin{array}{l}80 \% \\
10.0 \% \\
2.5 \% \\
7.5 \% \\
100 \%\end{array}$ & $\begin{array}{l}\text { (4) Self-discipline should be inculcated through } \\
\text { the principles of overload training. }\end{array}$ \\
\hline 5 & $\begin{array}{l}\text { Athletes do not treat opponents } \\
\text { as friends during competitions. }\end{array}$ & $\begin{array}{c}5 \\
6 \\
4 \\
1 \\
\text { Total } \\
\end{array}$ & $\begin{array}{c}32 \\
5 \\
2 \\
1 \\
40 \\
\end{array}$ & $\begin{array}{c}80 \% \\
12.5 \% \\
5 \% \\
2.5 \% \\
100 \%\end{array}$ & $\begin{array}{l}\text { (5) motivational speakers should be engaged to } \\
\text { talk on acceptance of opponents as friends in } \\
\text { sports }\end{array}$ \\
\hline 6 & $\begin{array}{l}\text { Athletes do not work hard on } \\
\text { performing difficult tasks at all } \\
\text { times. }\end{array}$ & $\begin{array}{l}2 \\
6 \\
7\end{array}$ & $\begin{array}{c}3 \\
28 \\
3\end{array}$ & $\begin{array}{l}7.5 \% \\
70 \% \\
7.5 \%\end{array}$ & $\begin{array}{l}\text { (6) Coaches should organize peer discussions on } \\
\text { the importance of diligence and sacrifice as a } \\
\text { medium of earning success in sport. }\end{array}$ \\
\hline
\end{tabular}


Development of Character Strategies by Coaches for University Athletes in Niger Delta Region of ..

\begin{tabular}{|l|l|c|c|c|l|}
\hline & & 8 & 6 & $15 \%$ & \\
\hline \multirow{4}{*}{7} & Total & 40 & $100 \%$ & \\
& Athletes do not encourage one & 2 & 2 & $5.0 \%$ & \\
& another when things are not & 3 & 1 & $2.5 \%$ & (7) Player councils should be constituted to \\
& working well during & 7 & 30 & $75 \%$ & resolve intra team conflicts on team cohesion in \\
& competitions. & 8 & 7 & $17.5 \%$ & sports. \\
\hline \multirow{5}{*}{8} & & Total & 40 & $100 \%$ & \\
& Players do not assist teammates & 6 & 2 & $5 \%$ & \\
& who are striving to be fielded & 7 & 39 & $7.5 \%$ & (8) Coaches and team captains should organize \\
& for competitions. & 8 & 2 & $5 \%$ & interactive computer video assisted programmes \\
& & Total & 40 & $100 \%$ & on team work and integration of new members. \\
\hline
\end{tabular}

From Table 4, Coaches adopted item 1 which specifies that sport fairs should be organized periodically to promote and reward athletes who display temperature are tolerance $(80 \%)$ which scored highest of all the items, as the strategy for players being angry at their teammate who make mistakes during play. The character trait of players withdrawing from practice of different skills, (is matched against the reaching of autobiography of past model athletes that demonstrated tenacity and perseverance $(80 \%)$ as a strategy. The social character trait of athletes obeying game rules only when it is convenient is matched with item 3 (explicit rewards and incentives relating to total allegiance and obedience should be communicated to athletes (72.5\%). University coaches adopted item 4 (self-discipline should be inculcated through the principles of overload training) which scored $80 \%$ as a match to player who easily give up during extra time of competitions on the trait of athletes to not treat opponents as friend during competitions coach adopted item 5 (80\%) (Motivational speakers should be engaged to talk on acceptance of opponents as friends in sports) as strategy. Coaches matched item 6(70\%) (Coaches should organize peer discussions on the importance of diligence and sacrifice as a medium of earning success) to athletes do not work hard on performing difficult tasks at all times. The trait which states that athletes do not encourage one another when things are not working well during competition is matched to item $7(75 \%)$ (Player councils should be constituted to resolve intra team conflicts on team cohesion in sports. Coaches of university athletes matched item 8 (coaches and team captains should organize interactive computer and video assisted programmes on team work and integration of new members.

\subsection{Moral Character Development Strategies}

\section{Discussions}

Coaches considered the use of motivational speakers to talk on the moral implications of getting opponent injured deliberately as a strategy for athletes who fake injury to gain advantage over opponent during sports. Reports from [31] show that motivational talks appeal to the conscience and enables athletes to make decisions leading to changes in character. Motivational speakers appeal to the emotions and enhances perspective-taking enabling athletes to take wise moral decision about care of fellow athletes in sport. On athletes breaking game rules if officials will not catch them, coaches adopted the strategy of coaches and athletes developing code of conduct that specify sanctions for rule breakers. [32] noted the effectiveness of written codes of conduct which embody structures for enforcing the sanctions by ethical conduct committee. The codes of conduct which are published should be distributed to athletes enables them to be more conscious of their character in sports. For athletes who encourage coaches to locate matches on bad playgrounds to gain advantage over opponents, coaches adopted the strategy of devoting substantial portion of post practice briefing session to discuss and stress the importance of integrity and honesty in sports. During the Arizona sport summit accord [33] it was suggested and adopted that coaches should make good use of post practice briefing session discussion to inculcate desirable moral values in sport.

Two strategies were endorsed by coaches for their colleagues who field non bona fide athletes in competitions .They include: demonstration of transparency in fielding of athletes and the organization of moral reasoning discussions on the rational for fielding mercenaries in university sport competitions. [34] posited that when coaches demonstrate transparency in dealing with issues relating to fielding athletes for competitions athletes are challenged to emulate and internalize such character traits. On moral reasoning [9] reasoned that good character results from individual's ability and capacity to engage moral reasoning and moral dialogue in resolving issues where athlete are in dilemma. Lange opines that when athletes use their reasoning skills to control themselves virtue results. On the act of protecting teammates who take performance enhancing drugs to perform in sports competitions coaches accepted that athletes and coaches should organize public campaigns to highlight through discussions the moral rationale of using drugs to compete with opponents. The Wisconsin Intercollegiate Athletic Conference [35], approved the use of public campaigns by players to educate the public and athletes on the moral implications of competing under the influence of drugs. Campaigns enhance personal reflective thinking by the participants in the exercise and enable the athletes to lead by example. 
Coaches matched the regular practice of traditions that reinforce tolerance and forgiveness to retaliating bad play by opponents in sport competitions. Coaches should reinforce tradition of caring for colleagues and opponents by showing courtesy. When athletes assist fallen athletes in the field of play it fosters the need for courtesy and care in sports rather than retaliation [36]. On players who deliberately deceive opponents to win, coaches accepted the organization of moral dialogue and dilemma discussion sessions for athletes, [36] explained that moral dilemma discussions sometimes called ethical decision making is a strategy in which athletes are presented moral issues by the coach to arouse interaction among athletes to resolve dilemmas. This strategy facilitates the application of athlete's moral reasoning skills in resolving conflicts and dilemmas they face in the field of play. Finally on moral character strategies, coaches matched the engagement of motivational speakers to appeal to the conscience of athletes who hurt opponents to win games.

\subsection{Social Character Development Strategies}

Coaches adopted the organization of sport fairs during which athletes who exercise tolerance and temperance are rewarded as strategy for players who are angry at their teammates for making mistakes. Josephson institute for center of sports [37] prescribed sport fairs where many sports are organized to display virtues that are acquired through sport participation. Sport fairs present opportunities to celebrate and reward outstanding character in sport thereby stimulating competition for aspiration to good behavior in sports. On athletes who withdraw from practicing difficult skills while training, the study of autobiographies of past model athletes who demonstrated tenacity and perseverance was recommended by university coaches. [9] also recommended that autobiographies of model athletes should be distributed to and read by athletes for discussions subsequently with coaches. Lange observed that reading autobiographies facilitates reflective thinking and it is a precursor for acquisition valued character traits.

Communication of explicit incentives and rewards relating to total allegiance to officials and rule was recommended by coaches as strategy for athletes who obey game rules only when it is convenient. Athletes have the orientation of knowing the outcome of behavior in sports. [38] is of the opinion that when coaches verbally express the expected rewards given to athletes who exhibit good character they are committed to practice skills that enhance development of character. On the habit of athletes giving up easily during extra time, coaches approved that self-discipline should be inculcated through the principles of over-load training. [39] asserted that when athletes focus on self-mastery and personal improvement through gradual increase of the workload, they are more likely to understand the purpose of self-discipline .Self-discipline is developed through consistent increase of athlete's hours of training. To tackle the problem of athletes who do not treat opponents as friends on the field of play, coaches endorsed the engagement of motivational speakers to discuss the need to see opponent players as friends during competitions. Motivational speakers teach and discuss issues passionately in an informal atmosphere. [40] observed that individual are challenged to think reflectively upon relating well with their opponents in the field of play. Coaches recommended the organization of peer discussion on diligence and sacrifice as panacea for resolving the issue of who do not work hard on performing difficult tasks at all times. [41], accepted peer discussion as a promising practice for developing character traits such as respect, fairness, self-discipline and hard work. These character traits are manifested through social-emotional behaviour such as being a good listener, understanding others point of view and understanding one's own and others feelings.

Coaches endorsed the constitution of player councils to resolve intra team conflicts and team cohesion as strategy for athletes who do not encourage each other when things are not working well during competition. Player council involves selecting model athletes for the purpose of providing them with a voice and choice in the team for resolving major social problems bordering on character [38]. On players who do not assist team mates who are striving to be fielded for competition, coaches approved the strategy of coaches and captains organizing interactive computer video assisted programmes on team work and integration of new members. The Arizona sport summit accord organized by Josephson [33] approved the use of computer and video assisted programmes where dummy recorded athletes play games showing cooperation and team cohesion. At the end of each session athletes interact by discussing problems arising from non-assistance.

\section{Conclusion}

Structured and validated strategies are needed for development of character of athletes through sport participation. University coaches adopted nine moral character strategies that include briefing sessions on discussing integrity and honesty, having character code of conduct, and demonstrating transparency amongst others. While eight social character strategies were adopted for university athletes. They include organization of sport fairs to reward athletes, providing autobiography of athletes of model character to read; lectures delivered by motivational speakers, and player councils constituted to resolve intra team conflicts. 


\section{References}

[1]. Armstrong, C. F., The Lessons of Sport class Socialization in British and American Boarding Schools. Sociology of Sport Journal (1), 1984, $314-331$

[2]. Sage, G., Does sport affect character development in athletes? The Journal of Physical Education, Recreation and Dance 69(1), $1998,15-18$.

[3]. Gouldli, D. C., Do sport Build character? A study of intramural sport programme of United States Air force. Academy (Published master thesis 2000

[4]. Igbanugo,V.C., Perspective view of Nigeria University Games. In Anugweje K.C. (Ed.) Multidimensional approach to sport development through the university system 2004

[5]. Oelstrom, T., Building the dream house with a foundation of character. Journal of College and character (2), 2003.

[6]. Arnold, P., The Virtues, Moral Education and Practice of Sport Quest 51. (1) 1999, 39-54

[7]. Parker, M., \& Stiehl, J., Personal and social responsibility. In D. Tannenhill, \& J. Lund (Eds.). Standards based curriculum. Boston, M.A: Jones and Bartlett 2004.

[8]. Pritchard, I., Character Education: Research prospects and problems. American Journal of Education 96 (4), 1988, 469-495.

[9]. Lange, C., Success Stories, Character and Personal Development; 2002, retrieved http://www.uh edu/hti/cu 2002iuo7/02.htm.

[10]. Rudd, A., \& Mondello, M.J., How do college coaches define character? A Qualitative Study with Division A Head Coaches, Journal of College and Character, 7 (3), 2006.

[11]. Dodge, A. \& Robertson, B., Justification for unethical behaviour in sport. The role of coach. Canadian Journal for women in coaching. (4) 4, 2004.

[12]. Brackenbridge, C., Spoil Sports understanding and preventing Sexual exploitation in Sport London New York, Rutledge 2001.

[13]. McNamee, M. J., Sport conduct; A Survey of sports spectators of the values and norms of selected professional sports. University of Gloncesteshire Chettenlan UK, 2001.

[14]. Stoll, S.K., Should we teach Morality? The issue of moral education. In a Jewett, L. Bain and C.D. Ennis (Eds.), The Curriculum Process in Physical Education (2nd) Dubuque, IA Brown and Benchmark, 1995.

[15]. Kohlberg, L., The Philosophy of moral development moral states and the Idea of justice. (New York, Harper and Row Pub 1981).

[16]. Austin, M., How can character be built through sports? Psychology Today (Online). http://www.psychologytoday.com/blog/ethicseveryone/201006/how-can-character-be-built through-sports, 2010.

[17]. Shield, D. L \& Bredemeier, B. J., Character development and physical activity Champaign, Human Kinetics 1995.

[18]. Rudd, A. \& Stoll, S., What type of character do athletes possess? An empirical examination of college athletes versus college nonathletes with the RSBH value judgement inventory. The Sports Journal.7, (2) 2004.

[19]. Bandura, A., Social Cognition theory of moral thought and action. In Kurtines W. M \& Gewirtz. J. L. Handbook of Moral Behaviour and Development. Vol. 1. (Lawrence Erlbaum Associates. Hillsides N. J. 1991).

[20]. Haan, N., Coping and defending: Processes of self-environment organization. (New York: Academic Press 1977).

[21]. Kavussanu, M., Morality in sport: In S. Jowett \& D. Lavallee (Eds.), Social psychology in sport (pp.265-277) (Champaign, IL: Human Kinetics 2007).

[22]. Eccles, J.S; and Gootman, J.A., Community programmers to promote youth development. (Washington, D-C: National Academy Press 2002).

[23]. Mugno, D.A\& Feltz, D.L., The Social Learning of aggression in youth football in the United States. Canadian Journal of Applied Sport Sciences, (10), 26-35, 1985.

[24]. Smith, M.D., Social Learning of Violence in mirror hockey. In F.L. Small \& R.E. Smith (Eds), (Psychological perspectives in youth sport) pp.91-106 1978), Washington DC. Hemisphere

[25]. Guivernau, M. And Duda, J.L., Moral atmosphere and athlete aggressive tendencies in young soccer players. Journal of Moral Education 51 (1), 67-85, 2002.

[26]. Stuart, M.E, \& Ebbeck, V., The influence of perceive social approval on moral development in youth sport. Pediatric Exercise Science, 7, 270-280 1995.

[27]. Borg, W.R. \& Gall, M.D., Educational Research: An Introduction, (London Longman Publishing Company 5th Ed. 1989).

[28]. Lickona, T., Education for character: How our schools can teach respect and responsibility.( New York, Bantam Books 1991).

[29]. Njoku, P. N., Healthy Ageing Intervention Model (HAIM) for secondary school teachers in Imo state, Unpublished Doctoral Thesis. University of Nigeria Nsukka 2003.

[30]. Ugwueze, F. C., Crisis management model for soccer clubs in south eastern states of Nigeria. Unpublished Doctoral Dissertation, University of Nigeria Nsukka 2010.

[31]. Gibbons, S. L. and Ebbecks, V., The effect of different teaching strategies on the moral development of physical education students. Journal of teaching in Physical Education. 17, 85-98, 1997.

[32]. Burnett, D., .Defeat Gamesmanship. National sportsmanship survey. pp5, 2005

[33]. Arizona Sports Summit Accord Arizona sports summit accord: Implementation strategies, Scottsdale, Arizona. CA: JICSE. Josephine Institute Center for Sports Ethics, 1999.

[34]. Bredemeier, B .J and Shields, D. L., Sport and Character Development. Research Digest (7) 1, 2006.

[35]. Wisconsin Intercollegiate Athletic Conference (WIAC) (2002) "Conversations on Character in Sport" NCAA Division III Initiative Grant - Final Report.

[36]. Schonert-Reichl, K.A. (2004). Teaching with moral dilemmas in the elementary and secondary school classroom strategies to develop students' moral reasoning, Paper presented at 2004, social Justice Conference. Retrieved July 2010 from $\mathrm{http} /$ www.betf.bc/social/social justice/teaching with moral delemma html.

[37]. Josephine Institute Center for Sports Ethics, Survey of high school athletes 2006: Are coaches teaching our young athletes the right way to play? CA: JICSE 2006.

[38]. Beller, J. M, \& Stoll, S. K., A moral reasoning intervention programmes for Division I athletes. The Academic Athletic Journal spring, 7 (5), 1992, 43-57.

[39]. Stephens, D., Goal Orientation and Moral Atmosphere in youth sport: An examination of lying, hurting and cheating 1993. Behaviours in girls' soccer. In Shields D.L, and Bredemeier B.J. (1995) (Ed.) Character development and physical activity. Champaign: Human Kinetics.

[40]. Stolls, S. K \& Beller, J. M., Do Sports Build Character? In J. R. Gerdy, (Ed.) Sports in School: The Future of an Institution. (New York, Teachers College Press) pp. 18 - 30, 2000.

[41]. Gano-Overway, L.A; Guivernau, Magyar, T.M.; Waldron, J.J. \& Ewing M.E., Achievement goal perspectives, perception of motivational climate, and sports personship: Individual and Liam effect psychology: Sport and Exercise 6, $2005,215-232$. 